\title{
Water Gasification of Fuel Oil and Natural Gas
}

\author{
by Toshihiko Kinoshita \\ (Tokai Ryuan Kogyo Co. Ltd)
}

\begin{abstract}
SYNOPSIS :- The author describes the present states of water gasification of fuel oil and natural gas in Italy according to his practical observation. In recent years hydrocarbon oils have been used for the hydrogen source in stead of coal and coke. He described the Fauser Process, the typical gasification process of fuel oil and natural gas, in detail and also introduced other several processes.
\end{abstract}

U.D.C. $662.61: 7: 625$ (43)

\section{最近の西ドイツ連邦鉄道における燃料事情}

一昭和 29 年 12 月 7 日例会講演一

鉄道技術研究所橫堀進

要旨：筆者は日本国鉄とドイツ連邦鉄道との孛換研究員の一員として，1953年12月から1954华 6 月 女で約 6 ケの間ドイツ連邦鉄道に關し調査研究を行つてきた。その中の燃料事情につき次の諸項 目にわけその概要を教告する。

すなわち，(1）西ドイツ連邦の出炭量と連邦鉄道の石炭消費量，(2）ドイッに扣ける石炭の分 類，（3）ドイツ炭の性啠，（4）機関車用炭，（5）煉炭，（6）熱管理，（７）一般用炭につき記 述べる。

\section{I 緒言}

箠者は日本国鉄とドイツ連邦鉄道と，研究員交換の 第 1 回目の一員として，1953年12月から1954年6月に 至る約 6 ケ月間，ドィッ連邦鉄道について研究調査を 行つてきた。この中で然料事情についての報告を以下 に記す。

\section{II 概 要}

西ドイッ連邦は面積 $264.2 \times 10^{3} \mathrm{~km}^{2}$ で日本の面積 $368 \times 10^{3} \mathrm{~km}^{2}$ の約 $2 / 3$ あり，人口は 4,758 万人で日本 の 8,400 万人の $56.5 \%$ あ゙あ。ここには匡有鉄道があ り、これをドィツ連邦鉄道 (Die Deutsche Bundesbahn) とよぶ。この鉄道（略称 D.B.B.）は営業距離 が $30,565 \mathrm{~km}$ で, 日本国有鉄道のそれの $20,007 \mathrm{~km}$ の 1.5倍に相当する。この鉄道の持つている車両数を比 較すると第1表のようになる。

\section{第 1 表 鉄道車両数比較}

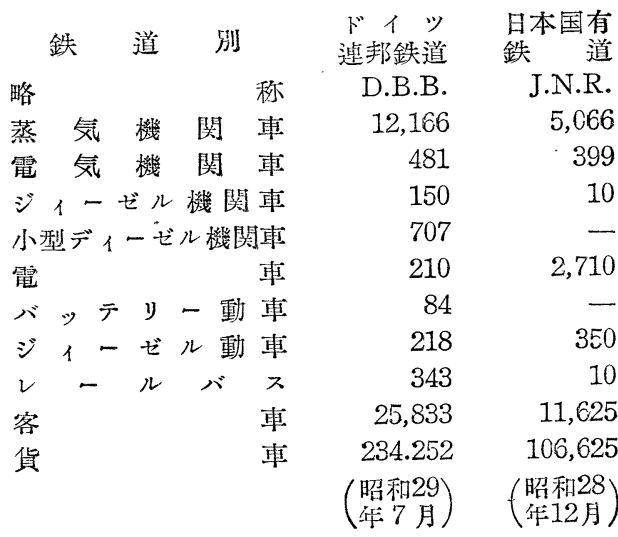

しからばこれに使われる燃料石炭はどの位であろう か。最近 5 年閒の実績をみるに第 2 表のようである。 
第 2 表 ドイツ連邦鉄道における石炭使用量

\begin{tabular}{|c|c|c|c|c|c|c|}
\hline \multirow{3}{*}{ 項目，単 } & \multirow{2}{*}{ 機関車用 } & \multirow{2}{*}{ 工場用 } & \multirow{2}{*}{ 合 計 } & \multicolumn{2}{|r|}{ 金 } & \\
\hline & & & & (石炭費) B & (国鉄全経賀)A & $(B / A) \times 100$ \\
\hline & $\times 10^{6} \mathrm{t}$ & $\times 10^{6} \mathrm{t}$ & $\times 10^{6} \mathrm{t}$ & $\times 10^{6} \mathrm{DM}$ & $\times 10^{6} \mathrm{DM}$ & $\%$ \\
\hline 1949 & 9.08 & 0.86 & 9.94 & 382 & $3,662.9$ & 10.4 \\
\hline 1950 & 8.79 & 0.73 & 9.70 & 370 & $3,830.8$ & 9.7 \\
\hline 1951 & 9.31 & 0.82 & 10.13 & 405 & $4,570.8$ & 8.9 \\
\hline 1952 & 9.34 & 0.77 & 10.11 & 474 & $5,389.5$ & 8.8 \\
\hline 1953 & 9.00 & 0.76 & 9.76 & 517 & $5,751.8$ & 9.0 \\
\hline
\end{tabular}

比較 (日本国有鉄道)

\begin{tabular}{|c|c|c|c|}
\hline $\begin{array}{l}\text { 項目, 単 } \\
\text { 位及年次 }\end{array}$ & $\begin{array}{l}\text { 譏閣車用 } \\
\times 10^{6} \mathrm{t}\end{array}$ & $\begin{array}{l}\text { 工場用 } \\
\times 10^{6} t\end{array}$ & $\begin{array}{l}\text { 合 計 } \\
\times 10^{6} t\end{array}$ \\
\hline 1949 & 5.33 & 0.83 & 6.16 \\
\hline 1950 & 4.97 & 0.76 & 5.73 \\
\hline 1951 & 5.37 & 0.94 & 6.31 \\
\hline 1952 & 5.17 & 0.91 & 6.08 \\
\hline 1953 & - & - & - \\
\hline
\end{tabular}

\begin{tabular}{|c|c|c|}
\hline 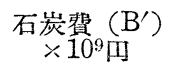 & $\begin{array}{l}\text { 国鉄全経費 }\left(\mathrm{A}^{\prime}\right) \\
\times 10^{9} \text { 四 }\end{array}$ & $\underset{\%}{\left(B^{\prime} / A^{\prime}\right) \times 100^{*}}$ \\
\hline 22.5 & - & - \\
\hline 18.8 & 140 & 13.4 \\
\hline 27.5 & 186 & 14.8 \\
\hline 34.7 & 220 & 15.7 \\
\hline- & - & - \\
\hline
\end{tabular}

な抢電気量は $673 \times 106 \mathrm{kWh}$ であり，ジィーゼル車用 然料のジィーゼル油は $25,120 \mathrm{t}$ で, 10,600,000DM に なる (1953年)。年間 900 万 $\mathrm{t}$ の石炭は 5 億DM (430 億円）で，連邦鉄道全経費の約 $9 \%$ に相当している。 石炭費が経理上大きくひびくことがわかる。しから ば，ドィッ国としての 全石炭生産量は幾何であろう か。これは年間 $125 \times 10^{6} \mathrm{t}$ で，その中で地元消費量を 除くと， $100 \times 10^{6} \mathrm{t}$ となる。すなわち，この中の約 10 \%をドィツ連邦鉄道が使つていることとなる。この年 閒 $9.5 \times 10^{6} \mathrm{t}$ という量は，1日当りにすると $26,000 \mathrm{t}$ である。これら産出量 $100 \times 10^{5} \mathrm{t}$ の石炭の中で, $62 \%$ を貨車が運び，その運賃は D.B.B. の全収入の16\%， 貨物収入の $25 \%$ となる。これをみると，石炭が D.B.B. として大切なことがわかる。この石炭の購大は D.B. B. と石炭販売会社 (Verkaufsgesellschaft) とが直 接取引きをやっている。

\section{III ドイツにおける石炭の分類}

順序として，ドィッに抢ける石炭の分類を示すと第 3 表のようになる。比較のために日本の分類表を附記 する。なおここれらの項目については後に記す。

\section{IV ドイツ炭の性犋}

(1) 成 分組 成

ドィッ炭の性質については色々の 報告が出ている が,ルールおよびアーヘン地区の石炭については, 灰分 および水分を除いた純炭分の揮発分を横軸にとつて， 緃軸に $\mathrm{C}, \mathrm{O}_{2}, \mathrm{H}_{\Xi}$ および $\left[\mathrm{H}_{2}-\left(\mathrm{O}_{2} / 8\right)\right]$ の值を示すと 第1困のごとくなる。

\section{(2) 発 熱 量}

発熱量と揮発分との関係は第 2 四のようになる。

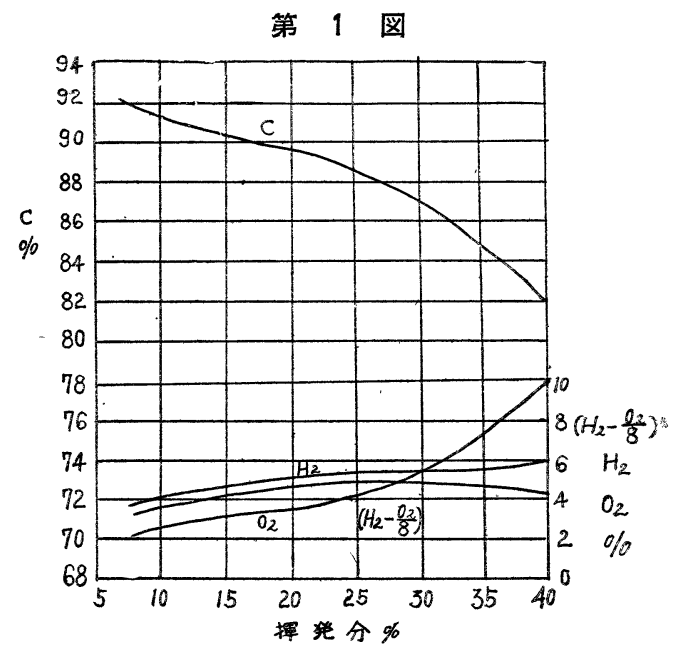

第 2 図

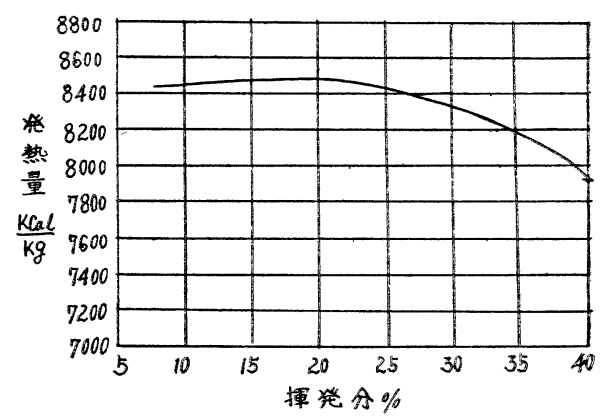

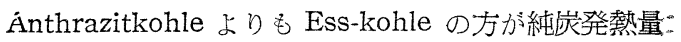

は高い。

（3）コークス化特性 
第3表 ドイツ石炭分類および佂格表

分類, 項目及種別

Förderkohlen

Gasförderkohlen

Bestmelierte

蒸気閏莗 $\left\{\begin{array}{l}\text { Stück } \\ \text { Knabbeln } \\ \text { Nuss } 1\end{array}\right.$

Nuss 2

Nuss 3

Nuss 4

Nuss 5

Koksfeinkohlen

gew. Feinkohlen ungew. Feinkohlen

Nuss. 4 (Aschearm)

Staubkohlen

Mischkohle
粒曰灰分水分

$\mathrm{mm} \%$ \%

- $\quad \begin{gathered}10 \sim 20 \quad- \\ -\end{gathered}$

$\begin{array}{lll}- & 10 & - \\ - & 10\end{array}$

80以上 $5 \sim 7$ -

150/120 5 7 4以下

$\sim 80 \sim 50 \quad 5 \sim 7 \quad 4$ 以下

$50 \sim 30 \quad 5 \sim 7 \quad 4$ 以下

30 18 5 8 5以下

$18 \sim 10 \quad 6 \sim 8 \quad 5$ 以下

$10 \sim 6 \quad 6 \sim 8$ 5以下

10/6 $0.6 \sim 8$ 10以下

$10 / 6 \sim 0 \quad 7 \sim 9 \quad$ 10以下

$10 / 6 \sim 0 \quad 11 \sim 15$

18〜10 4以下

$1 \sim 0 \quad 10 \sim 20$

$50 \sim 0 \quad 12 \sim 18$
蒸気機関車用

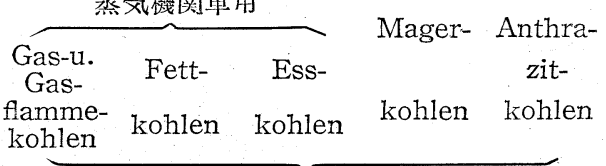

**水分指よび灰分を除いたものに対する割合

比較:

日本の分類

\begin{tabular}{|c|c|}
\hline 種 & 揮発分 $(\%)$ \\
\hline 無 櫭 炭 & $3 \sim 7$ \\
\hline 半 無 煙 炭 & $7 \sim 13$ \\
\hline 牛歴 青 炭 & $13 \sim 19$ \\
\hline 高度瀝 青炭 & $19 \sim 32$ \\
\hline 低度瀝青炭 & $32 \sim 50$ \\
\hline
\end{tabular}

誈：との価格々1953年 5 月 1 日当時のものを DM（ドイッマルク）単位で表わしたもので，1DM 々日本円86币に相当する。

\section{第 4 表 コ一クス 化 特 性}

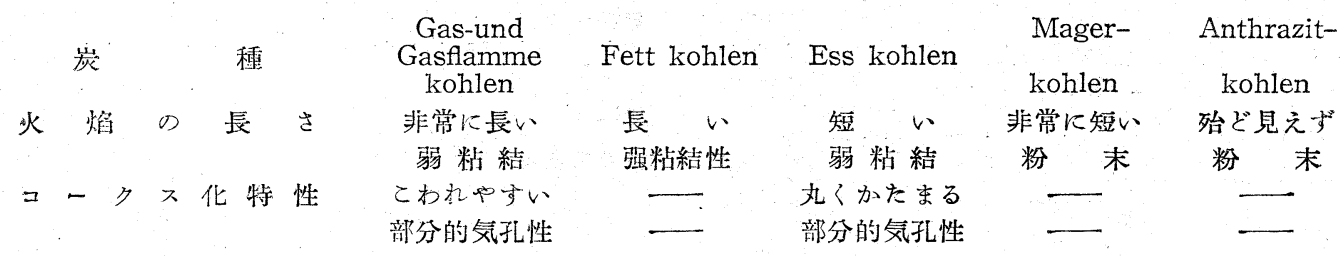

第4 表に示すごとくである。

(4) 石炭灰の性質

ルール炭の灰は最大含有量が $7 \%$ ある。日本炭に

比し灰分が著しく少ない。若し，燃焼したあとに発生

する灰が多孔性であるならば，問題はないが，さむな
く、て愹融性のものであるとClinker 老作つて焚く上に 困難を感ずる。そこで灰がとけるときにどういう特性 在示すかか問題になる。 $5 \mathrm{~mm}$ 角, 厚さ $3 \mathrm{~mm}$ の立方 体の灰の塊を作り, Erhitzungsmikroskop という高 温炉につけた顕微鏡で灰の愹融特性を調べる。温度上 
第 3 図

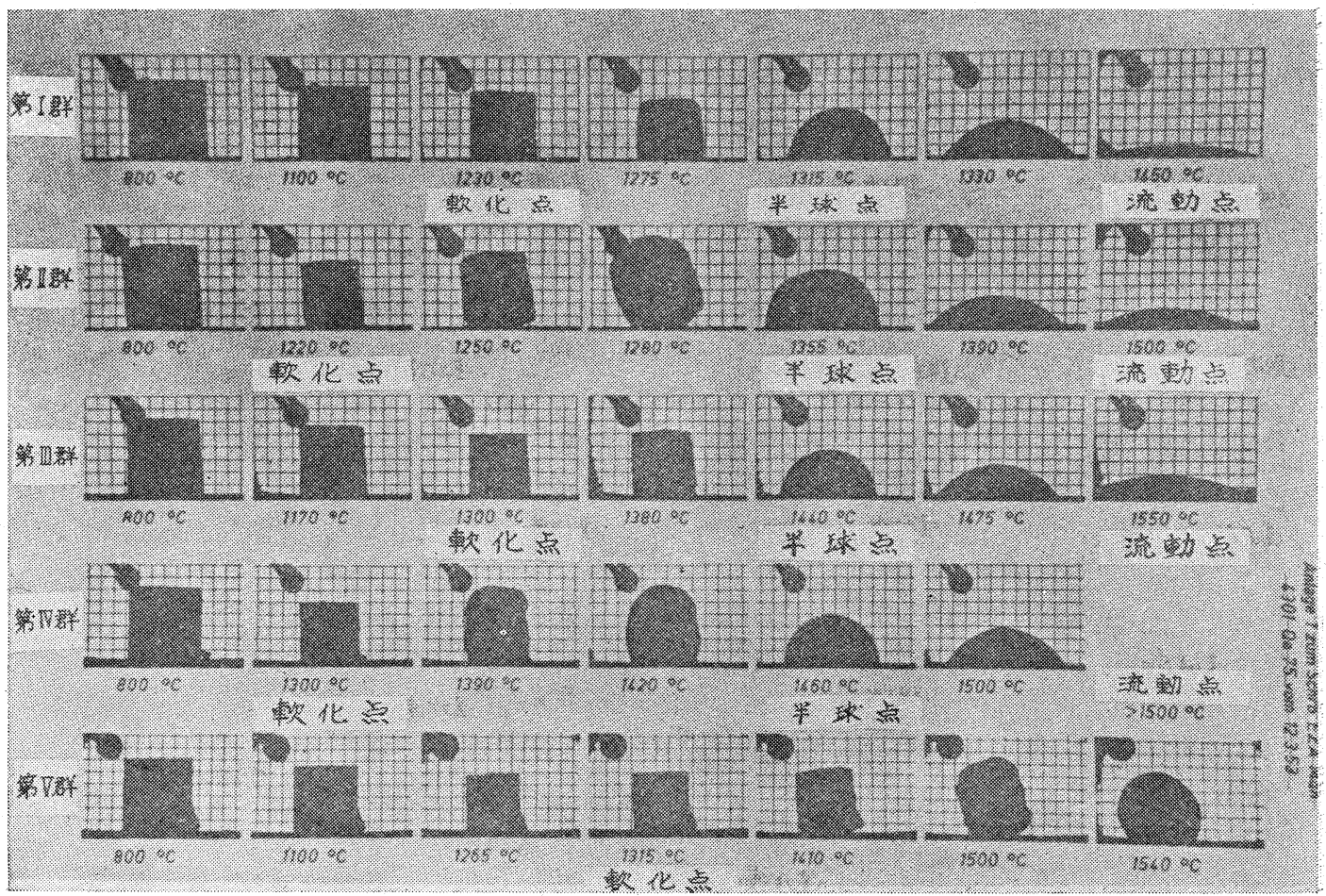

昇につれての,この灰の変形を写真にとつてゆく。そ の例点第 3 図に示す。

灰塊が変形しはじめたところが軟化点（Erweichnugspunkt) E で，灰がとけはじめて半円状になつた ところが愹融点 (Schmelzpunkt) $\mathrm{S}$ とよばれ，E点 とS点との間が軟化域 (Erweichungsbereich) であ

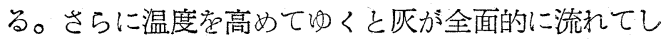
まうことがある。これが流和点 (Fliesspunkt) F と いう温度で， $\mathrm{S}$ と $\mathrm{F}$ との間を熔融域という。この $\mathrm{E}$,

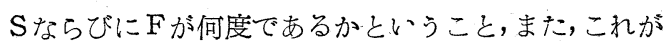
気流の性質によつていかに変るかということが，石炭 灰の, 従つて石炭の燃燒時の特性を左右することとな る(DIN-51730)。このためには Leitz 社製の Erhitzungsmikroskop がよいといわれる。ドイッ国鉄の技 術研究所では, 灰の愹融特性から次の 5 つの種類に分 類している(第 3 図)。

第1群 軟化域が低く 1,200 1,350 $\mathrm{C}$ またはとれ以 下で，膨脹しないもの，このような石炭をたくとク リンカーを生じやすく，機関車用としては一般に不 適当で，燃料層を薄くしてたく必要がある。 第 2 群 軟化域が $1,200 \sim 1,350^{\circ} \mathrm{C}$ 位で低く, 膨脹の 大きいもの，クリンカーが低温でできるが，通気性
がある。これも燃料層が薄いときだけに使える。 第 3 群 軟化域が高く, 1,300 1,450 $\mathrm{C}$ 位で，膨脹: しないもの，燃料層が厚いと気密性のクリンカーを゙ 作る。これも燃料層を薄くして使う。

第 4 群 軟化域が高く, $1,300 \sim 1,400^{\circ} \mathrm{C}$ で, 膨脹が大 きいものこれはクサンカーが塊状になり，燃焼上 に支障しない。

第 5 群 愹融点 (半球点) $か 51,500^{\circ} \mathrm{C}$ 以上の湯合

これも灰が粒状になり，然焼上に支障はない。

以上の結果は酸化気流すなわち, 坒気過剩の下での 赛績である。睘元気流に対しては未だ実験中ではつき りしたことはわからない。ただ，一つの例として，気 流によつてこれらの点が変化することを示すと次のと 抢りである(第5 表)。

\section{第 5 表 Ruhr 炭}

$\begin{array}{cccc}\text { 気 流 別 } & \begin{array}{c}\text { 軟化点 } \\ \left({ }^{\circ} \mathrm{C}\right)\end{array} & \begin{array}{c}\text { 熔融点 } \\ \left({ }^{\circ} \mathrm{C}\right)\end{array} & \begin{array}{c}\text { 流和点 } \\ \left({ }^{\circ} \mathrm{C}\right)\end{array} \\ \text { 酸化気流中て } & 1,240 & 1,425 & 1,600 \\ \text { 䢬元気流中て } & 1,160 & 1,310 & 1,530\end{array}$

このルール炭に対しては還元気流中では愹融点が約 $100^{\circ} \mathrm{C}$ 低下寸ることがわかつた。このことは燃料層の゙ 上面にあつて，還元気流中に大ると愹融点が低くなり， 
クリンカーを生じやすいことになる。これは燃焼上か らいえぱ,あまり燃料層を厚くしてはいけないという ことになる。しかし，もつと多くの石炭についてこ れと同じょうな還元気流中での $\mathrm{E}, \mathrm{S}, \mathrm{P} 3$ 点の変化を 求めてみればまた別の分類にすることも考えられる。 この試験に使う Leitz 社の Erhitzungsmikroskop はドィッ国鉄では, 鉄道技研の 化学研究所の他に, Opladen, Hamburg-Altona, Fulda, München-Neuaubing 抢よび Stuttgart の熱管理試験所に設備され ている。主要なるボィラ工湯 (Babcock, VKW, Steinmüller): 各社の試験室なぼにもあつて, 灰の研 究に努めている。

\section{1. 一 般}

蒸気機関車ボィラはその構造上，他のボィラに比し 著しく大きい燃焼率で石炭を燃焼させる。すなわち， 陸上据付ボイラで $120 \sim 150 \mathrm{~kg} / \mathrm{m}^{2} \mathrm{~h}$ の燃焼率のもの が, 蒸気機関車ではこの $5 \sim 6$ 倍の $500 \sim 700 \mathrm{~kg} / \mathrm{m}^{2} \mathrm{~h}$ になつている。このように, 火格子単位面積当りに然 焼させる石炭の多いということは便用する石炭に対し てある條件を与光ることとなり，どの石炭でもよいと いうわけには行かなくなる。

\section{2. 機関車に焚く燃料}

（1）燃焼率が大きいから揮発分の大きいものが然焼 速度が早いので望ましい。よつて Mager-Kohle と Anthrazit-Kohle は適していない。

（2）Ess-Kohle は揮発分が少いから然え方が遅い。 (3) Gas-flamme-Kohle では燃料層を成可くうす くして，ガス化したところに多量の $\mathrm{O}_{2}$ が行くよう にする。短時間に小量宛くべるのがよい。

（4）この 2 つの間にある Fettkohle は火室で然え 切つてしまう。この Koks は “Blumenkohle” と 呼ばれて火床を多孔性 (Locker) にする。従つて, これは機関車用として最も適したものである。従つ て D.B.B. はドィッで産する Fettkohle の約 70\% というものをこれに使つている。

(5) 次に Ess-Kohle は揮発分が少く，仕事量の小 さいときに適していて, Gas-flammkohle は逆に揮 発分が多く，仕事量の大きい，仕事量の変化の大き いときに適している。Fettkohle はこの中間にな る。使用者側からい光ば，常に同一炭破の，同一銘 柄のものを使えばよいのであるが，大量の石炭をそ う無理もいえず，ある條件の下に使つている。

（6）昔は Förderkohle (切込炭) を使つたが粉炭 が多く，従つて，機関車に使つた湯合にシンダ発生
量が多くて不経済である。えこで $30 \mathrm{~mm}$ 以上の塊 炭を50\%以上含むものとして Bestmelierte 使つ た。しかしそれでも不充分で，今日では Stück ( $80 \mathrm{~mm}$ 以上) 塊炭と Nuss 1 とを使い, 特にルー 儿地区では 120/80mm の塊岸を集めて（水洗いし た後で), これを Knabbel と呼び鉄道用に供給さ れている。

これの特徴は，(1) 洗炭で角がとれるから, 粉炭 発生量が少い。(2) 品質および大きさが一様である。 (3) 大塊を割るという助土の仕事がなくてすむ。こ のようにして, 今日のドィッ連邦鋘道の使用炭は塊 炭だけで, 粉炭が完全に除去されていることは注目 すべきである。日本国鉄で, $13 \mathrm{~mm}$ 以下の粉炭が 30 〜 40\%混合してあるのに比較して，全く羡しい次第 である。灰分が $5 \sim 7 \%$ 程度なのも日本に比して羡 しいことである。なお，ルール地区から出る Fettkohle の70\%は鉄道用に使つている。

VI 煉炭 (Brikett)

日本と同じようにドィッにおいても煉炭を機関車用 然料に使つている。岸珸からでる石炭の中, 粉炭が50 \%, Nüsse が 30\%，塊崖が 15\%で，塊岸だけを使う わけに行かず昔は粉孷の多い石炭を使つたので，これ に $3 \mathrm{~kg}$ 位の大きさの熯炭を混ぜて然焼させ，主とし て火床形成の目的で使つた。しかしすでに述へたよう に，塊㟶が大部分になつてくると，この本来の使命存 失つた**。しかし，粉孷が相当大量にあるし，かつ廉 価であるので，これを加工して，枯崖を作ることにし， それを機関車燃料として使うことを考えた。ドィッに おける煉炭は次のようなものがある(第6 表)。

\section{第6表、ドイッ煉宸}

種 類重 量 Ess- $\overbrace{\text { Mager Anthrazit- }}^{\text {原料炭種 }}$

\begin{tabular}{|c|c|c|c|c|}
\hline & & & & \\
\hline Stückbriketts & $10 \mathrm{~kg}$ & $63^{*}$ & $x$ & $x$ \\
\hline Stückbriketts & $7 \mathrm{~kg}$ & 63 & $x$ & x \\
\hline Stückbriketts & $3 \mathrm{~kg}$ & 63 & $x$ & \\
\hline Stückbriketts & $1 \mathrm{~kg}$ & 66 & $x$ & \\
\hline Wurfetbriketts & $450 \mathrm{gr}$ & 63 & $x$ & \\
\hline Kissenbriketts & $360 \mathrm{gr}$. & 60 & $x$ & \\
\hline Eierbriketts & 50gr. & 64 & 66 & 68 \\
\hline Nussbriketts & $15 / 18 \cdot \mathbf{2 4}$ & 66 & 68 & 68 \\
\hline
\end{tabular}

**ただ今日でもタンク機関車のようなもので仿 $3 \mathrm{~kg}$ の徚炭をつみかさ悋ると Tender K多量につめる ので特別なときに注使つている。 
すなわち，はじめは表中の Stückbriketts を使つて いたが，やがて石炭と同じ大きさのEierbrikettsを使 うょうになつた。しかし，握拳(にぎりこぶし)大の Kissenbrikett に移行した。原料は Esskohle の粉炭 に，石炭ピッチ（Steinkohlenteerpech）７\%を混ぜ て揮発分18〜20\%のものとなつている。Fettkohleの 揮発分の少いものに相当する。日本では 50〜40gr, 位 の,大きさでいえば Eierbriketts に相当するものを使 つている。ドィッでも Kissenbriketts に移る前に両 者の比較試験を長期に亘り行つたが，350gr.の方がょ いということになつた。煉炭はドイツ連邦鉄道とし $\tau$, 月間 30,000 40,000 $t$, 年間 360,000 480,000 t を使つている。

筆者はドィツ滞在中に一徚炭工湯を見学する機会を 得た。日本の工湯と比較してみて著しく異るように思 つたことは，ピッチの混入方法である。ピッチは石炭 ピッチで愹融点 $105^{\circ} \mathrm{C}$ 位のもの常に加熱して，大 きな Drum 缶の中に保存しておく。大きな回転円筒 があつて，ここへ粉岸が送り込まれ，気流に乗つて他 端へ行く。同じ側からピッチの12〜16気圧, $250^{\circ} \mathrm{C} に$ 加熱したものを霧状にふきかけて，この直径 $1.5 \mathrm{~m}$,

長さ $8 \mathrm{~m}$ 位の Trommel 中で完全にまぜる。後はバ ケットコンベアーにのつて Nieder に大るところ日本 のと変りはない。Brikettig-Press も同じである。こ の混入方法で，ピッチの使用量が $7 \%$ (日本は10\%) ですむこととなるらしい。大きさは $350 \mathrm{gr}$. であるか らにぎり拳大で, 大きい Brikett-Press で加工時のピ ッチは $90^{\circ} \mathrm{C}$ 位, ピッチの軟化温度は $72 / 95^{\circ} \mathrm{C} *$ であ る。

ピッチ (Pech) は 100D.M/t (8,600円/ t ) で粉炭 の 40DM/ t $(3,440 円 / t)$ に比し割高であるとなげい ていた。この会社では 50gr. 位の Eierbriketts も，ま た, $3 \mathrm{~kg}, 10 \mathrm{~kg}$ という大きいものも作れるようになつ ていたが，当日はKissenbriketts だけを作つていた。

\section{VII 燃 料 節 約}

\section{1. 機 関 車}

燃料節約は日本と同じょうに各種の方法で努力して いて，次のような構造を試験している。これらの詳細 については別の機会に説明したい。

(1) 自動給炭機 (Mechanical Stoker)

(2) Hulson 形火格子

* Brikettig-Press 泣 4 列で $24 \mathrm{t} / \mathrm{h}$ 位の能力のもの 1 台をもつている。この会社胡產 $30,000 \mathrm{t}$ 位であ つた。
(3) 混合式給水加熱器

(4) Franco Crosts 形給水加熱器

2. 集 賞

石炭 $1 \mathrm{t}$ の節約に対して, 当時の石炭洒格43D.M/tの 額を支給する。ごれは各機関区単位で行い。個人別の 加味は機関区で行う。

\section{D.B.B. の一船用崖}

1. 蒸気機関車以外の 使用部面として，(1) 発電所 そ，(2) 工湯動力および暖房用とがある。現在の電気 運転区間では，水力が $75 \%$ ，火力が $25 \%$ の割になつて いる。この湯合の火力発電所は，大体において低質燃 料在便うし，ボイラ効率も蒸気機関車よりもよいから 然料費は非常に節約される。この電化区間は漸次拡大 される予定で，1956年ルール地区の Hamm-Düsseldorf 間に 20 編成の電車を入れるだけで年間 80,000 t の石炭が節約される予定であるし，ルール地区が全部 電化されれば，この地区だけで 650〜700×106kWh の年間電力使用量となり，えの他を合計すると，1.5 × $10^{9} \mathrm{kWh}$ となり，燃料使用量は $2 \times 10^{6} \mathrm{t}$ (これは $9.5 \times 10^{6} t$ の約 $20 \% に$ 相当する) 減ることになる。こ の中のある部分は石炭に，ある部分は褐炭（BrannKohle）を登電所で使ゔことにより差引かれるが，全 部の電力を火力発電でまかなうとしても，0.7〜0.8 $10^{6} \mathrm{t}$ 位の石炭使用量となるであろう。電化も 1 つの 石炭節約対策である。

\section{2. 一般用炭に対する D.B.B. の熱管理}

工湯用ボイラおよび暖房用ボイラに対しては Minden 鉄道中央局に熱管理課という一つの主管の課があ つて，燃料使用個所をみているわけであるが，発電所 は München にある電気車の部門が電化という面で 面倒をみている。しかし, 発電所としては現在, München の南方に Penzberg という発電所があり, ここでは発熱量 $3,400 \mathrm{kcal} / \mathrm{kg}$ ，灰分 $32 \%$ ，水分 $16 \%$ と いう石炭を焚いて（この土地で産する）いる。これは 上記の枠に大っていない。

その他のボイラは全部厳重な熱管理を行つて, 石炭 の節約に努めている。寒いドィッ, 冬の長いドィッで は，暖房用炭も相当量になる。しかし，これも年々割 当をへらしてきている。このことについては別の機会 に述ベたい。(個人住宅で年閒 1,000 2,000DM 位の 石炭費を使う)。

\section{IX 結一語}

ドィツ連邦鉄道 (D.B.B.) は年間 950 万 $\mathrm{t}$ の石炭を 使い，その綴費は 430億円で，連邦鉄道全予算の約 9 $\% に$ に相当する。 
この石炭費を節約するために色々の努力をしており， その概要を述へた。石炭はドィッ連邦鉄道用に最も適 合した性能のものを関倸業者方提供していて，灰分 5 $\sim 6 \%$, 発熱量 7,600 7,700kacl $/ \mathrm{kg}$ の $80 \mathrm{~mm}$ 以上 の塊炭, 或は 50/80 mm の中塊炭を使つている。機関 車以外でもその節約に努力している。

交献

1. Ruihklohlen-Handbwch. (Vierte Auflage) 1954. Gemeinschaftsorganisation Ruhrkohle G. m. b. H. S. 393. Abb. 271. Tab. 86.
2. Preisliste für Kohle. Mai-1. 1953.

3. Eigenschaften der Lokomstivkohlen nach Zechen geordnet. 1953.

4. Technishe Lieferbedingzungen für Kolle, Koks, Brikett, usw März. 1953.

5. Probst, Weyers:-Die Steinkohle und ihre Verfeuerung in der Lokomotive. Die Lokomotivtechnik. Jan. Feb. ss. 8-12, 25-28. 1954.

6. Weyers:-Die. Steinkohle im Eisenbahnwesen. Vortrag auf der Tagung "Energie und Steinkole". Dortmund. Feb-4 1954.

\title{
Information on the Fuel used by Western Germany Railway
}

\author{
by Susumu Yokobori
}

(Railway Technics Research Institute)

\begin{abstract}
SYNOPSIS :-The author, one of the exchange investigators of Japan National Railway for Western Germany Railway (D. B. B.) investigated D. B. B. during 6 months from Dec., 1953. to Jun., 1954. In this report, the outline of the following items of the fuel used by D. B. B. is described; (1) the coal production in Western Germany and the coal consumption by D. B. B. (2) classification of coal in Germany. (3) character of German coal. (4) coal for locomotive. (5) briquette. (6) promotion of heat economy. (7) coal for general use of D. B. B.
\end{abstract}

U.D.C. 668.736 .32

\section{安水中のフェノールの除去 \\ 一昭和 29 年 12 月 7 日例会講演会講演—— \\ 川㥓製鉄株式会社千葉製鉄所 金 安 仁 一 郎}

要旨：[I]工場廃水淨化を目的として建設されたわが国最初の安水中のフェノール除去につき, 昭和28年12月より運転したオット一式脫酸設硔の概要, 特徵和よび作業实績を述べる。

〔II〕溶剤ベンゾールルタール塩基を添加した場合にフェノールの抽出效率が上昇するととを認 めたのでその実験結果和よび実際に工場運転に移した作業实績を述べ。

\footnotetext{
I 緒言

工場廃水の淨化は古くからその必要性を認められて 抢り, 現在欧米に抢いては河川の淨化, 工湯廃水の淨

化に関する法律の制定とともに，おのおの工場におい て処理設備が設けられその徹底化が行われているが， 残念ながらわが国においては法律の制定もなく，僅か
} 